\title{
Free space availability and larval substratum selection as determinants of barnacle population structure in a developing rocky intertidal community
}

\author{
Todd E. Minchinton ${ }^{1, *}$, Robert E. Scheibling ${ }^{2}$ \\ ${ }^{1}$ Department of Oceanography and ${ }^{2}$ Department of Biology, Dalhousie University, Halifax, Nova Scotia, Canada B3H $4 \mathrm{~J} 1$
}

\begin{abstract}
Variation in settlement and recruitment of the barnacle Semibalanus balanoides (L.) was experimentally investigated in the high, mid and low intertidal zones at 2 adjacent sites ( $A$ and $B$ ) on a rocky shore in Nova Scotia, Canada, following a rare occurrence of ice-scouring. Manipulations in $100 \mathrm{~cm}^{2}$ quadrats at each intertidal height involved removal of various components of the sessile macrofauna and macroflora, removal of the total community and a control treatment. The availability of free space on the substratum in each quadrat was measured prior to the onset of settlement to determine whether differences in the density of barnacles among treatments were due to differences in the availability of free space or to manipulation. Where the density of settlers was high, it was positively related to the availability of free space suggesting that settlement was a simple function of the availability of free space. However, the pattern of settlement varied from the onset to the end of settlement: quadrats from which only barnacles had been removed were occupied early in the settlement period and later-arriving larvae were restricted to less favourable sites where free space was available. Thus, settlement preferences may be masked when the supply of larvae is saturating or the duration of the selction experiment is too long. Where the density of settlers was low and free space was non-limiting, there was no relationship between the density of settlers and the availability of free space. In the high intertidal zone at Site A, the density of settlers was greater in treatments with ephemeral algae (wetter quadrats) than in those without (drier quadrats). In general, early post-settlement mortality in treatments where algae had been removed increased with intertidal height, whereas in treatments where algae were present it remained relatively constant among heights. Post-recruitment mortality did not differ significantly among treatments in the high intertidal zone, suggesting that factors which influence selection of the substratum by cyprid larvae and promote early post-settlement survival may be particularly important in determining subsequent population structure of barnacles in this zone. Post-recruitment mortality, mainly due to predation by whelks, was highest in the low intertidal zone at both sites and did not differ significantly between treatments. In the mid intertidal zone at Site B, whelk foraging appeared to be constrained by desiccation stress and post-recruitment mortality was highest in treatments with Fucus spp. Where predation is intense, initial selection of the substratum by cyprid larvae may have little effect on the subsequent population structure of barnacles.
\end{abstract}

\section{INTRODUCTION}

Although not a novel idea (see Young 1987), recent studies have emphasized larval settlement as a key determinant of the population structure of adult sessile marine invertebrates (Grosberg 1982, Yoshioka 1982,

\footnotetext{
- Present address: Institute of Marine Ecology, Zoology Building (A08), University of Sydney, New South Wales 2006, Australia
}

Underwood \& Denley 1984, Caffey 1985, Connell 1985, Gaines \& Roughgarden 1985, Roughgarden et al. 1985, 1987, Bushek 1988, Davis 1988, Underwood \& Fairweather 1989). Settlement occurs when a planktonic larva permanently attaches to the substratum (Keough \& Downes 1982, Connell 1985); it is a function of the supply of planktonic larvae to an area, the behavioural and physical processes which bring the larvae into contact with the substratum and the availability of suitable sites for settlement. Subsequently, agents of 
mortality affect the distribution and abundance of recently settled individuals and determine the population structure of adults.

Factors influencing settlement of barnacle larvae have been studied extensively. In the water column, larval abundance and age may inhibit settlement (Knight-Jones 1953, Crisp \& Meadows 1963, Crisp 1974, Lewis 1978) or alter selection of the substratum (Ritschoff et al. 1984). Near the substratum, local hydrodynamics (eddy currents, shear stress) may affect the settlement of cyprid larvae (Walton-Smith 1946, Crisp 1955, Wethey 1986, Mullineaux \& Butman 1991). A rapid increase in light intensity causes a sinking reaction in cyprid larvae (Crisp \& Ritz 1973). On the substratum, surface contour and microheterogeneity, rock type, organic films and resident flora may influence settlement (Crisp \& Barnes 1954, Barnes 1955, Crisp 1961, 1974, Crisp \& Meadows 1963, Strathmann \& Branscomb 1979, Hudon \& Bourget 1981, Strathmann et al. 1981, Hudon et al. 1983, Wethey 1986, Chabot \& Bourget 1988, Le Tourneux \& Bourget 1988, Maki et al. 1988, Raimondi 1988a). Conspecifics (and their chemical attractants) promote a gregarious settlement response of cyprid larvae (Knight-Jones 1953, Knight-Jones \& Crisp 1953, Crisp 1955, Crisp \& Meadows 1962, Luckens 1970, Larman \& Gabbott 1975, Wethey 1984, Chabot \& Bourget 1988, Raimondi 1988b). The resident macrobenthic community may directly prevent settlement via obstruction by algae (e.g. whiplash effects) (Pyefinch 1948, Menge 1976 , Grant 1977, Hawkins 1983, Petraitis 1983), bulldozing by herbivores (Dayton 1971, Denley \& Underwood 1979, Petraitis 1983), filtration of planktonic larvae (Barnes 1959, Mileikovsky 1974) or by pre-empting space (Denley \& Underwood 1979, Gaines \& Roughgarden 1985, Chabot \& Bourget 1988).

The factors mediating selection of the substratum by barnacles have been determined mainly from laboratory experiments in which it is relatively simple to test the response of cyprids to isolated settlement cues. Extrapolation of such studies to the field is unlikely to be successful. Under natural conditions, factors inducing settlement act in combination and their degree of influence in time and space is variable (Hudon et al. 1983). Given this predicament, how can the important components of settlement dynamics be resolved in the field so that the distribution and abundance of settlers and adults can be predicted from observations on shore and in the adjacent water column?

Hudon et al. (1983) and Le Tourneux \& Bourget (1988) took a detailed analytical approach relating the settlement of barnacles in the field to a combination of potential physical and biological cues. Alternatively, Gaines \& Roughgarden (1985) and Roughgarden et al. (1985) viewed the settlement of barnacles synthetically as a mass action process in which settlement is a simple function of the availability of free space adjusted for such factors as planktonic larval supply, site immersion time and average bulk flow over the substratum.

In this study, we sought to combine both these approaches in examining settlement of the barnacle Semibalanus balanoides (L.) in a developing rocky intertidal community in Nova Scotia. The objectives of the study were: (1) to examine the relationship between the density of settlers and the availability of free space on the substratum at 3 intertidal heights; (2) to relate variation in densities of settlers and barnacles surviving $3.5 \mathrm{mo}$ after the main period of settlement to manipulations of the dominant sessile macrofauna and macroflora at each intertidal height; (3) to examine if, and how, selection by larvae for the various manipulated substrata changes from the onset to the end of settlement; and (4) to compare rates of early post-settlement and post-recruitment mortality among treatments within and among intertidal heights. By accounting for the availability of free space in each quadrat at the onset of settlement, significant differences among treatments will refute the claim that settlement is a simple function of the availability of free space and show the factors which enhance or inhibit settlement and determine adult population structure.

\section{METHODS}

Study site and organism. The study was conducted from March to September 1988 on an exposed icescoured rocky shore at Sandy Cove, Nova Scotia,

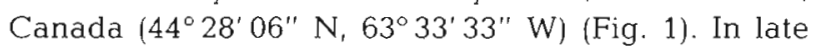
March to early April 1987, an anomalous occurrence of ice-scouring denuded this and other exposed rocky intertidal shores along the Atlantic coast of Nova Scotia near Halifax (see Minchinton \& Scheibling 1991 for more details). At Sandy Cove, the intertidal macrofauna before the ice scour included barnacles (Semibalanus balanoides), mussels (Mytilus edulis), herbivorous gastropods, (Littorina littorea, L. obtusata, L. saxatilis, Lacuna vincta and Notoacmaea testudinalis), predatory gastropods (Nucella lapillus), amphipods and isopods. The intertidal macroalgae consisted of rockweeds (Fucus evanescens, $F$. vesiculosus, F. spiralis, F. distichus and Ascophyllum nodosum), Irish moss (Chondrus crispus), a fleshy red algal crust (Hildenbrandia rubra) and various ephemeral annual species. After the ice scour, all that remained were isolated Fucus spp. holdfasts, a few barnacles in the high intertidal zone, and some crevice-dwelling macrofauna. More protected sites near the study area were left partially or fully intact depending on their degree of exposure. 


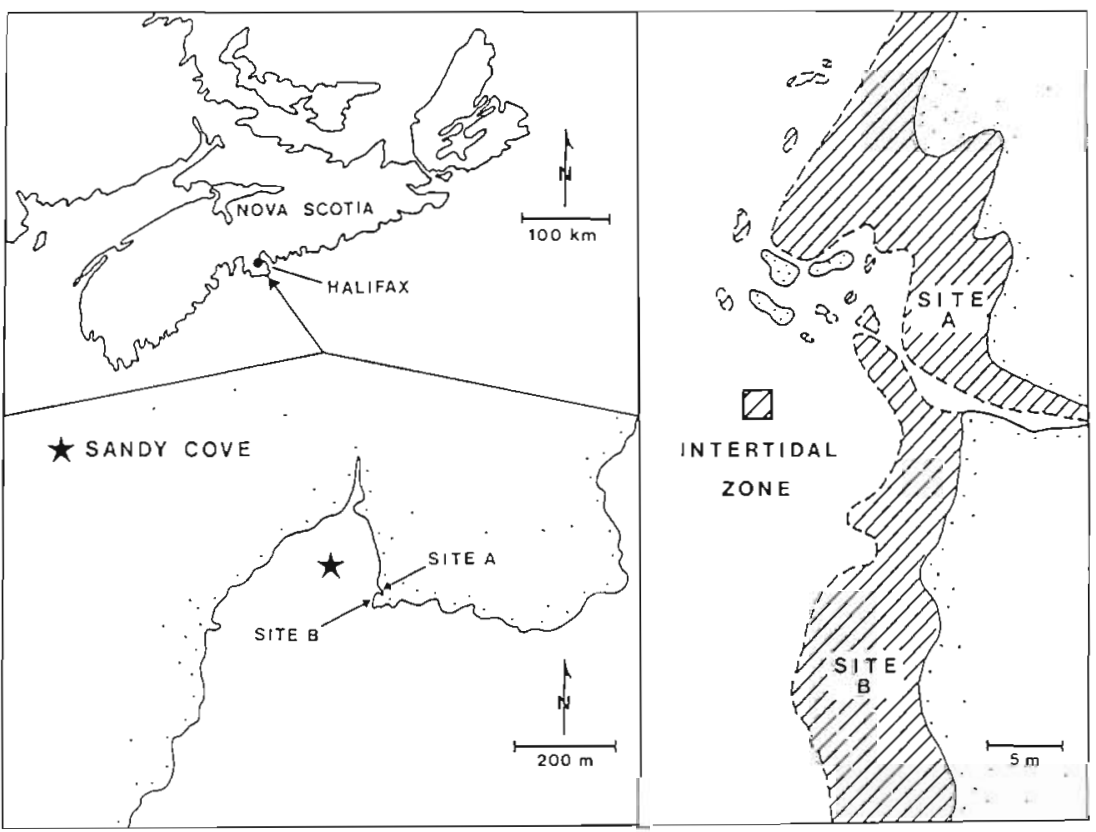

Fig. 1. Location of study sites at Sandy Cove, Nova Scotia, Canada

are brooded by adults of $S$. balanoides until late February to early March when hatched nauplius larvae are first released into the water (Bousfield 1953). Planktonic nauplii develop through 6 instars into competent, non-feeding cyprid larvae which settle and attach permanently on shore from mid-April to early June. In 1988, recently settled cyprids were first observed on 22 April and last observed on 12 August. The main period of barnacle settlement was from 26 April to 15 June (Minchinton \& Scheibling 1991).

Experimental design. The major components of the macrobenthic community at each intertidal height were manipulated in $10 \times 10 \mathrm{~cm}$ quadrats. Treatments included: mussel (Mytilus edulis) removal, barnacle (Semibalanus balanoides) removal, ephemeral algae removal,

The shoreline at Sandy Cove consists of gradually sloping granite platforms with narrow crevices and large rock outcrops. Two study sites (A and B) were chosen in this area, approximately $25 \mathrm{~m}$ apart and with the same aspect (Fig. 1). Site B is seaward of Site A, and somewhat more exposed to wave action and storm swell. Waves usually pass by Site $B$ before reaching Site A. Site A is protected from the south by Site B and from the west by rock outcroppings at the seaward limit of the intertidal zone.

Semibalanus balanoides is a dominant sessile invertebrate along the rocky intertidal shores of Nova Scotia (Bousfield 1953). Before the ice scour, barnacles were present in the high and mid intertidal zones at both sites (R. E. Scheibling \& A. R. O. Chapman unpubl. data), but absent from the low zone at Site $B$. There are no data available for the low zone at Site A. After the ice scour, barnacles settled throughout the intertidal zone at both sites. Typically, autumn-fertilized eggs
Fucus spp. removal and total community removal. There was one control treatment at each intertidal height where the natural community was undisturbed. Since not all components of the community were present (or manipulated) at each height the number of treatments differed among heights at each site (Table 1). There were usually 6 ( 5 in the mid and low zones at Site B) replicates per treatment arranged in a randomized block design in the high, mid and low intertidal zones at Sites $\mathrm{A}$ and $\mathrm{B}$. The blocks were $1.5 \mathrm{~m}$ long by $1 \mathrm{~m}$ wide and extended alongshore at each intertidal height. One replicate per treatment was randomly assigned to the fixed quadrats in each block. All quadrats were spaced at least $10 \mathrm{~cm}$ apart and marked with screws fitted into plastic wedge anchors placed in drill holes.

The treatments were initiated in March and April 1988, prior to the onset of settlement by cyprids. Barnacles were removed by prying them off the rock with a scalpel blade, mussels by using forceps, fucoids

Table 1. Manipulations in the high, mid and low intertidal zones at Sites A and B at Sandy Cove

\begin{tabular}{|lccccc|}
\hline Treatment & & Site A & & & Site B \\
& High Zone & Mid Zone & Low Zone & High Zone & Mid Zone \\
Low Zone
\end{tabular}


by sliding a scalpel blade under the base of the holdfast and ephemeral algae by using forceps and gently brushing the substratum with a toothbrush and repeated rinsing (the latter treatment likely removed some of the microbial film). The total community was removed with a paint scraper and wire brush and the substratum was burned with a propane torch and brushed again to remove any remaining films or crusts, which simulated ice scour. After the onset of barnacle settlement, mussels, ephemeral algae and Fucus spp. that settled in quadrats were carefully removed from the appropriate treatments using a scalpel and forceps so as not to disturb recently settled barnacles. The new cohort of barnacles was not removed from any treatment.

Density of settlers. The density of metamorphosed barnacles and cyprids was measured in each quadrat on 6 dates from the onset of settlement until the end of the main period of settlement (22 April, 27 April, 10 May, 23 May, 6 June, and 15 June) and on 2 subsequent dates (1 August and 27 September). The low intertidal zone at Site B was frequently inaccessible at low tide and could not be adequately monitored for settlement. The density of settlers on each quadrat was calculated as the sum of increases in the number of metamorphosed individuals plus cyprids between successive sampling dates from the onset of settlement until the end of the main period of settlement. We recognize that the density of settlers, and therefore, early post-settlement mortality, may be underestimated at these sampling frequencies ( 5 to $14 \mathrm{~d}$ ). In this paper, we use the term 'settlement' or 'settler' to describe the patterns of arrival of barnacles or estimates of density made from the onset of settlement until the end of the main period of settlement and the term 'recruitment' to describe estimates of density of barnacles made at any other time after the main period of settlement, while specifying the date when the estimate was made.

At Sandy Cove, Semibalanus balanoides almost invariably settled on 'free space', i.e. substratum not occupied by dead or alive sessile macrofauna or algal holdfasts, but possibly covered by microbial films or algal crusts. The few individuals that settled on macrofauna or fronds of Fucus spp. were not included in analyses. A $100 \mathrm{~cm}^{2}$ plastic plate with 30 randomly located $3 \mathrm{~mm}$ holes was placed over each quadrat and the number of holes overlying free space gave an estimate of the percentage of free space in that quadrat. In order to determine what part of the differences in density of barnacles between treatments was attributable to differences in the composition of species on the substratum rather than the availability of free space, densities of barnacles were standardized for the availability of free space. This standardization was done by dividing the density of barnacles on each quadrat by the percentage of free space in that quadrat at the onset of settlement.

The relationship between the density of settlers and the availability of free space at the onset of settlement was determined by using data from quadrats of all treatments at each intertidal height. However, because the density of settlers varied between blocks at a given intertidal height, the density of settlers on each quadrat was standardized for differences in settlement between blocks before relating it to the availability of free space. This standardization was done by dividing the density of settlers on each quadrat within a block by the sum of the densities of settlers on all quadrats in that block and is termed relative settler density.

Patterns of settlement. To determine if selection by larvae for the various manipulated substrata changed from the onset to the end of settlement, the rate of settlement on each quadrat was calculated for each of the 5 time intervals from 22 April to 15 June. The rate of settlement was calculated as the increase in the number of metamorphosed individuals plus cyprids between successive sampling dates divided by the number of days between successive sampling dates. The rate of settlement in each quadrat for each time interval was standardized for the availability of free space in that quadrat at the beginning of the interval. Change in availability of free space for each time interval was determined by the product of the change in availability of free space due to barnacle settlement from 22 April to 15 June and the proportion of the density of barnacles settling during each time interval relative to the density of settlers from 22 April to 15 June. Settling barnacles accounted for most of the change in availability of free space during this time.

Recruitment and mortality. Early post-settlement mortality for each quadrat was estimated as the difference between the density of settlers (as defined in 'Density of settlers') and the number of barnacles surviving at the end of the main period of settlement (15 June) expressed as a percentage of the density of settlers. Post-recruitment mortality for each quadrat was estimated as the difference between the greatest density of barnacles (15 June or 1 August) and the number of barnacles surviving on 27 September expressed as a percentage of the greatest density of barnacles.

Data analysis. Densities of barnacles were $\log (x+1)$ transformed and percentage mortality data were arcsine transformed prior to analysis of variance (ANOVA). To improve the arcsine transformation at the extreme ends of the range, $0(0 / n)$ and $100(n / n)$ $\%$ mortality estimates were replaced by $1 /(4 n)$ and $1-1 /(4 n)$ respectively, where $n=$ the density of set- 
tlers or barnacles on 15 June or 1 August (Zar 1984). This correction prior to transformation was performed to offset inflated or underestimated mortality estimates which can occur in quadrats with only few barnacles. Because there was only 1 replicate of each treatment in each block, Tukey's test for nonadditivity was done prior to ANOVA to test the assumption of no interaction of the main effects. Nonadditivity was detected in only 3 cases, each for the rate of settlement in the high intertidal zone for some time intervals during the first half of the settlement period. In these cases, there was a relatively fast rate of settlement in 1 or 2 treatments and very little or no settlement in the others (see Fig. 2a). ANOVA was not done in these cases.

Separate 2-way ANOVAs (block, treatment) were used to test the null hypothesis of equality among treatment means for the density of settlers, the density of barnacles on 27 September, early postsettlement mortality, post-recruitment mortality and the rate of settlement for each time interval in the high, mid and low intertidal zones at Sites $A$ and $B$. Student-Newman-Keuls (SNK) multiple comparisons were used to detect significant differences among treatment means after ANOVA. The null hypothesis was rejected for $p<0.05$ in all cases (ANOVA and SNK). F- and p-values given in the text refer to the results of ANOVA. Linear regression was used to examine the relationship between relative settler density and the availability of free space on the substratum.

\section{RESULTS}

\section{Patterns of settlement}

Mean rates of barnacle settlement in each treatment from the onset of settlement until the end of the main period of settlement are presented in Fig. 2 for each intertidal height at each site (except the low intertidal zone at Site B). In the high intertidal zone at Site $A$, the pattern of settlement among treatments was generally consistent over time (Fig. 2a). Settlement rates in treatments with ephemeral algae were greater than those in treatments in which ephemeral algae had been removed. At the end of the main period of settlement, the settlement rate was significantly greater in the undisturbed control treatment in the high zone at Site A than in treatments in which ephemeral algae had been removed $(F=4.8, p<0.05)$ (Fig. 2a). In the high zone at Site $B$, the rate of settlement was not significantly different among treatments at any time, but was much greater in the treatment in which Fucus spp. had been removed than in all other treatments at the end of the main period of settlement (Fig. 2a). Thus, even at these low densities of settlers, by the end of the main period of settlement, there was evidence of selection by cyprids among treatments.

In the mid intertidal zone at Site $A$, the overall rate of settlement for all treatments combined declined over the main settlement period (Fig. 2b). At the onset of the settlement period ( 22 to 27 April), the rate of settlement was significantly greater in all other treatments than in
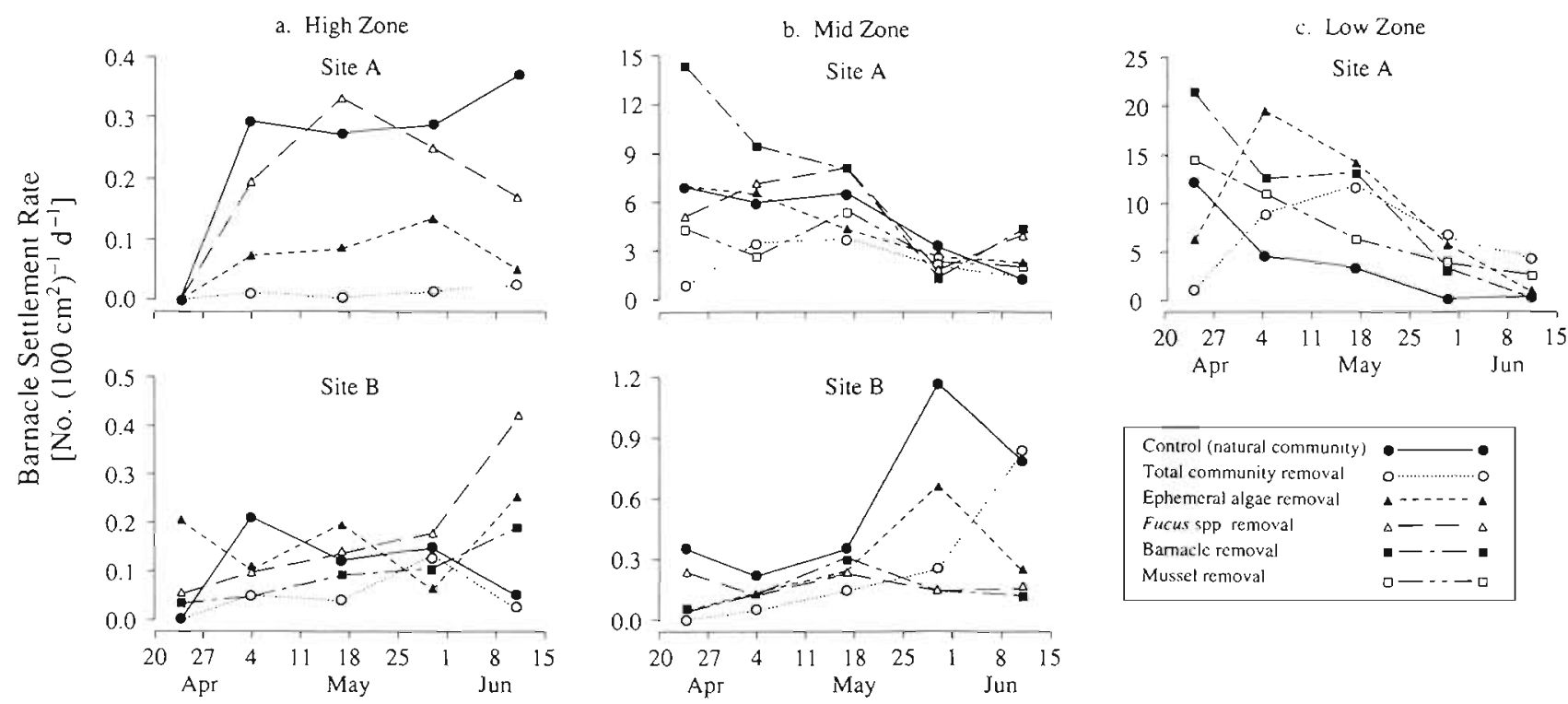

Fig. 2. Semibalanus balanoides. Mean rate of settlement (ind. $100 \mathrm{~cm}^{-2} \mathrm{~d}^{-1}$ ) for 5 time intervals from the onset of settlement (22 April) to the end of the main period of settlement (15 June) in 1988, in treatments in the (a) high and (b) mid intertidal zones at Sites A and B and (c) low intertidal zone at Site A. Note differences in scale on $y$-axes. Rates are plotted at the mid points of each interval 
the one in which the total community had been removed $(F=4.9, \mathrm{p}<0.01$ ) (Fig. $2 b)$. From 10 to 23 May, the rate of settlement in the treatment in which barnacles or fucoids had been removed was significantly greater than in the treatment in which the total community had been removed $(F=3.6, p<0.05)$. After 23 May, however, the rate of settlement in the mid zone at Site $A$ was low and not significantly different between treatments. In the mid zone at Site $B$, the overall rate of settlement for all treatments combined was an order of magnitude less than in the mid zone at Site A (Fig. 2b). In this zone, the rate of settlement in the control treatment was significantly higher than in most other treatments after 23 May $(p<0.01$ for both time intervals after 23 May) (Fig. 2b).

The pattern of settlement among treatments in the low zone at Site $\mathrm{A}$, the zone of greatest settlement, varied from the onset of settlement to the end of the main period of settlement and the overall rate of settlement for all treatments combined declined (Fig. 2c). At the onset of the settlement period ( 22 to 27 April), the settlement rate was significantly lower in treatments in which the total community had been removed than in all other treatments $(F=5.8, \mathrm{p}<0.01)$ and, as in the mid zone at Site $A$, was greatest in the treatment in which barnacles had been removed (Fig. 2b, c). By the end of the main period of settlement ( 6 to 15 June), however, there had been a complete reversal of conditions: the rate of settlement was significantly greater in the treatment in which the total community had been removed than in the control treatment or treatments in which only barnacles or ephemeral algae had been removed $(F=4.9, \mathrm{p}<0.01)($ Fig. $2 \mathrm{c})$.

\section{Density of settlers}

The density of settlers refers to the cumulative number of metamorphosed individuals plus cyprids that settled in a quadrat from the onset of settlement until the end of the main period of settlement standardized for the availability of free on the substratum prior to the onset of settlement (see Table 2). At Site $A$, the density of settlers in the natural community relative to the density of settlers in any other treatment within each zone increased with intertidal height, whereas the density of settlers in treatments in which ephemeral algae had been removed relative to the density of settlers in any other treatment within each zone decreased with intertidal height (Table 2).

In the high intertidal zone at Site $A$, the density of settlers was significantly greater in treatments with ephemeral algae than in treatments in which ephemeral algae had been removed ( $F=10.4, p<0.001)$ (Table 2). Similarly, in the high zone at Site $B$, the density of settlers was large in the treatment in which Fucus spp.

Table 2. Mean ( \pm SE) density of barnacle settlers, density of barnacles on 27 September (158 d after the onset of settlement on 22 April), and \% free space available on the substratum prior to the onset of settlement in 6 ( 5 in the mid and low zone at Site B) $100 \mathrm{~cm}^{2}$ quadrats for each treatment in the high, mid and low intertidal zones at Sites A and B. Barnacle densities have been standardized for the availability of free space on the substratum prior to the onset of settlement. A rough estimate of unstandardized (actual) barnacle densities can be obtained by multiplying the mean density for any treatment by the mean \% free space for that treatment. "No such treatment at that intertidal height; ND: no data for that treatment

\begin{tabular}{|c|c|c|c|c|c|c|}
\hline \multirow{2}{*}{ Treatment } & \multicolumn{3}{|c|}{ Site A } & \multicolumn{3}{|c|}{ Site $B$} \\
\hline & Settlers & $27 \mathrm{Sep}$ & Free space & Settlers & 27 Sep & Freespace \\
\hline \multicolumn{7}{|l|}{ High zone } \\
\hline Total community removal & $0.3 \pm 0.2$ & $0.7 \pm 0.2$ & $100.0 \pm 0.0$ & $3.2 \pm 1.1$ & $2.3 \pm 0.9$ & $100.0 \pm 0.0$ \\
\hline Barnacle removal & $\cdot$ & . & - & $6.3 \pm 1.7$ & $6.6 \pm 1.1$ & $96.1 \pm 1.6$ \\
\hline Ephemeral algae removal & $4.0 \pm 1.6$ & $3.9 \pm 1.7$ & $96.7 \pm 1.2$ & $7.0 \pm 2.4$ & $4.8 \pm 2.1$ & $93.3 \pm 1.7$ \\
\hline Fucus spp. removal & $11.1 \pm 2.8$ & $7.2 \pm 1.3$ & $98.9 \pm 0.7$ & $11.6 \pm 3.5$ & $13.7 \pm 5.1$ & $96.1 \pm 1.0$ \\
\hline Control (natural community) & $13.9 \pm 3.8$ & $9.4 \pm 2.8$ & $97.8 \pm 1.1$ & $6.9 \pm 1.4$ & $5.6 \pm 1.6$ & $93.3 \pm 4.0$ \\
\hline \multicolumn{7}{|l|}{ Mid zone } \\
\hline Total community removal & $123.2 \pm 33.1$ & $109.5 \pm 25.6$ & $100.0 \pm 0.0$ & $9.2 \pm 3.0$ & $10.6 \pm 2.9$ & $100.0 \pm 0.0$ \\
\hline Mussel removal & $157.6 \pm 31.7$ & $143.3 \pm 27.3$ & $73.3 \pm 4.4$ & $\cdot$ & $\cdot$ & · \\
\hline Barnacle removal & $286.7 \pm 73.2$ & $239.1 \pm 59.0$ & $98.9 \pm 0.7$ & $10.0 \pm 4.0$ & $3.2 \pm 1.3$ & $86.7 \pm 1.1$ \\
\hline Ephemeral algae removal & $208.2 \pm 57.8$ & $165.0 \pm 47.5$ & $76.1 \pm 10.0$ & $17.3 \pm 3.8$ & $7.9 \pm 2.1$ & $94.7 \pm 2.3$ \\
\hline Fucus spp. removal & $233.0 \pm 43.7$ & $219.5 \pm 38.2$ & $76.1 \pm 4.0$ & $9.7 \pm 5.3$ & $9.8 \pm 4.8$ & $88.7 \pm 1.7$ \\
\hline Control (natural community) & $205.4 \pm 61.2$ & $172.5 \pm 56.5$ & $56.7 \pm 10.7$ & $29.6 \pm 7.0$ & $3.1 \pm 1.1$ & $91.3 \pm 1.7$ \\
\hline \multicolumn{7}{|l|}{ Low zone } \\
\hline Total community removal & $334.5 \pm 35.6$ & $127.2 \pm 25.2$ & $100.0 \pm 0.0$ & ND & $1.4 \pm 0.5$ & $100.0 \pm 0.0$ \\
\hline Mussel removal & $286.6 \pm 79.5$ & $126.5 \pm 41.4$ & $56.0 \pm 7.1$ & $\cdot$ & $\cdot$ & . \\
\hline Barnacle removal & $381.2 \pm 92.0$ & $96.8 \pm 30.3$ & $73.9 \pm 9.3$ & . & $\cdot$ & . \\
\hline Ephemeral algae removal & $458.1 \pm 66.0$ & $169.1 \pm 27.1$ & $69.5 \pm 8.8$ & . & . & . \\
\hline Control (natural community) & $142.8 \pm 47.3$ & $31.8 \pm 8.8$ & $30.6 \pm 6.4$ & ND & $0.0 \pm 0.0$ & $16.0 \pm 5.3$ \\
\hline
\end{tabular}


had been removed and small in the treatment in which the total community had been removed, although there was no significant difference between these treatments due to large variation in settlement in the treatment in which Fucus spp. had been removed $(F=1.3, \mathrm{p}<0.30)$ (Table 2). Although there were significant differences among treatments in the rate of settlement at various time intervals throughout the main period of settlement in the mid intertidal zone at both sites, there were no significant differences in the cumulative number of settlers over the main period of settlement (Site $A$ : $F=1.7, \mathrm{p}<0.20 ;$ Site B: $F=3.2, \mathrm{p}<0.05$, but SNK revealed no significant differences between treatments) (Table 2). In the low intertidal zone at Site A, the density of settlers in the undisturbed control treatment was significantly less than in all other treatments except the treatment in which mussels had been removed $(F=3.8$, $\mathrm{p}<0.05$ ) (Table 2). As in the mid intertidal zone at Site A, the density of settlers was also relatively large in the treatment in which barnacles had been removed in the low zone (Table 2). Both of these zones had a large cover of barnacles prior to manipulation (i.e. removal of barnacles), and may therefore represent particularly favourable locations for settlement. Although the low intertidal zone at Site B could not be adequately monitored for settlement, the density of barnacles was at least 50 ind $100 \mathrm{~cm}^{-2}$ on quadrats which had been completely denuded, whereas no barnacles were observed amid the mussel bed in the natural community

At Site $A_{2}$ relative settler density (see definition in 'Methods - Density of settlers') on quadrats of the various treatments was positively related to the availability of free space on the substratum (Fig. 3), which explained 14 and $42 \%$ of the variation in the density of settlers in the mid and low intertidal zones respectively. The availability of free space was virtually unlimited in the high intertidal zone at both sites and in the mid intertidal zone at Site B ( $>90 \%$ on average; see Table 2), and therefore, was not related to the density of settlers.

\section{Recruitment and mortality}

At Site A, early post-settlement mortality generally increased with intertidal height in treatments in which algae had been removed (ephemeral algae and/or Fucus spp.) and remained relatively constant or decreased with intertidal height in treatments with algae (Fig. 4a) indicating that the presence of algae is increasingly important to survival of recently settled barnacles as one moves upshore. Although there were no significant differences in early post-settlement mortality among treatments in either the high or mid intertidal zones at both sites (high zone, Site A: $F=2.9$,

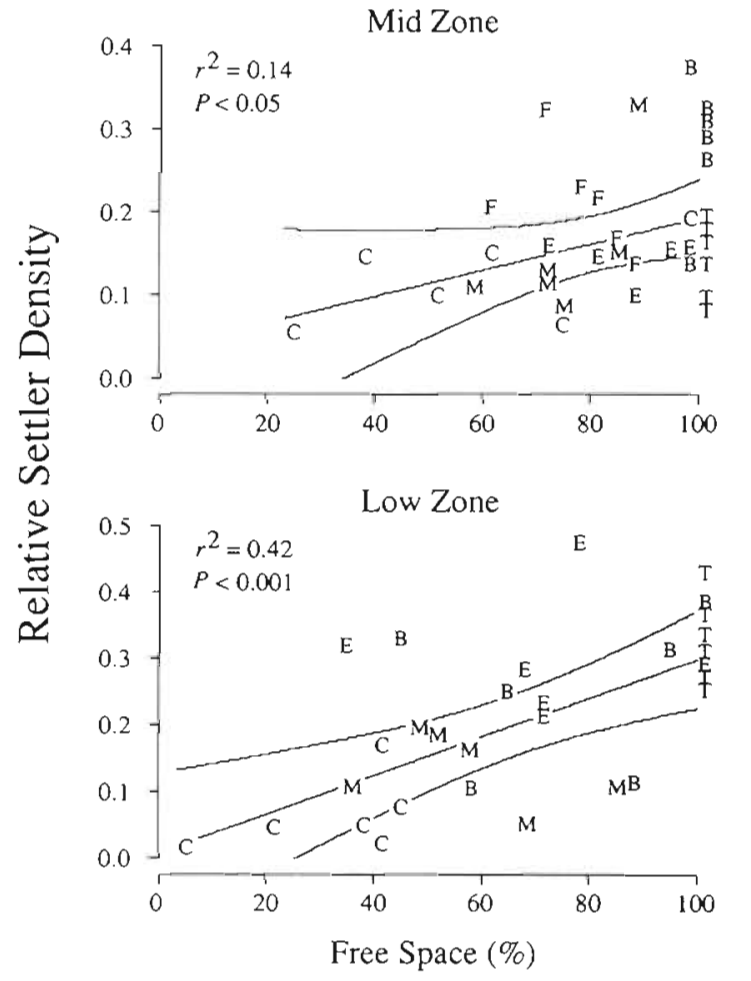

Fig. 3. Semibalanus balanoldes. Regression of relative settler density (see definition in 'Methods - Density of settlers') in each quadrat as a function of percent of the availability of free space on the substratum in that quadrat for the mid and low intertidal zones at Site A. Symbols for treatment types given in Table 1. Boundaries around regression lines represent $95 \%$ confidence limits

$\mathrm{p}<0.10$, Site $B: F=1.4, p<0.30$, mid zone, Site A: 1.2 , $\mathrm{p}<0.35$, Site $\mathrm{B}: F=2.5, \mathrm{p}<0.10$ ), some consistent patterns are present (Fig, 4a). In the high zone at Site A, early post-settlement mortality was highest in the treatment in which ephemeral algae had been removed. High early post-settlement mortality may also be expected in the treatment in which the total community had been removed, however, few barnacles settled in this treatment, and consequently, the estimate of early post-settlement mortality is based on the survivorship of only a small number of individuals. At Site B, early post-settlement mortality was high in the treatment in which the total community had been removed in both the high and mid zones and in the treatment in which Fucus spp. had been removed in the mid zone (Fig. 4a). In contrast to the high and mid zones at Site B, early post-settlement mortality in the low intertidal zone at Site A was lowest in the treatment in which the total community had been removed, significantly lower than in the control treatment $(F=$ 4.3, p<0.05) (Fig. 4a)

In the high intertidal zone at both sites, postrecruitment mortality did not differ significantly 
a. Early Post-Settlement Mortality

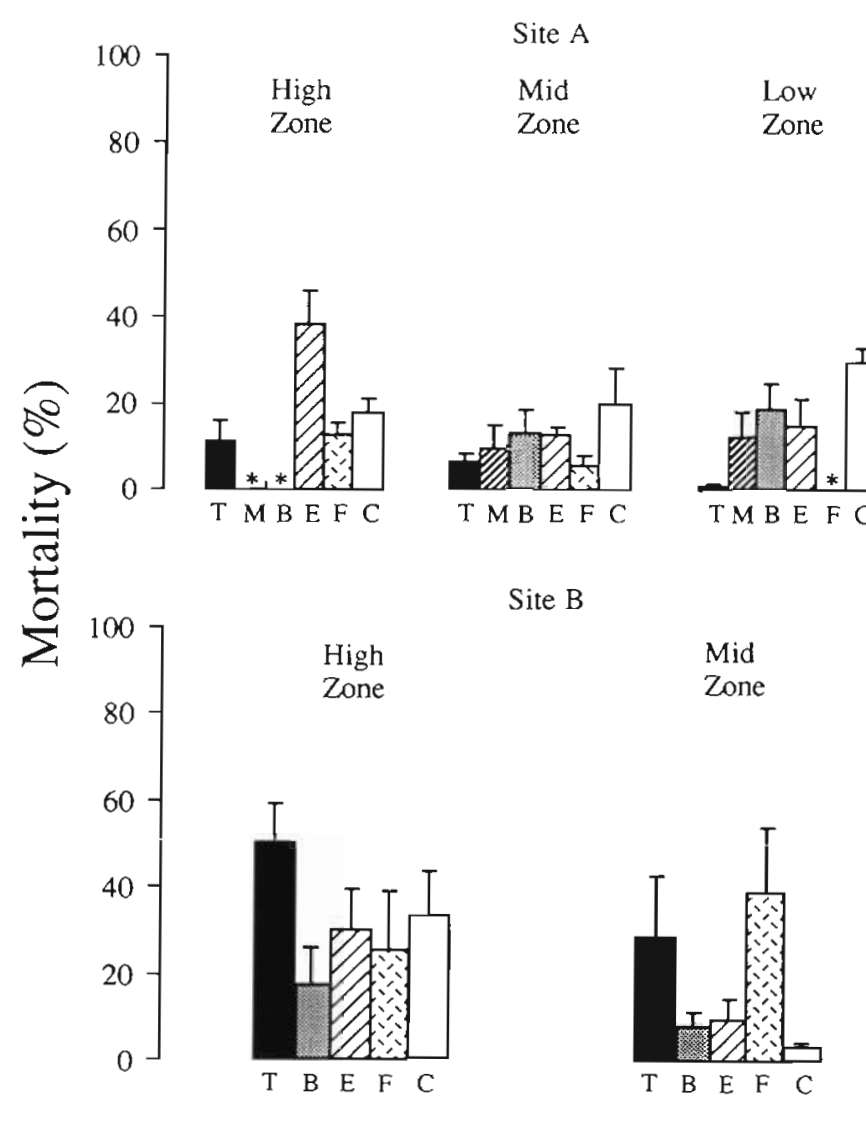

b. Post-Recruitment Mortality
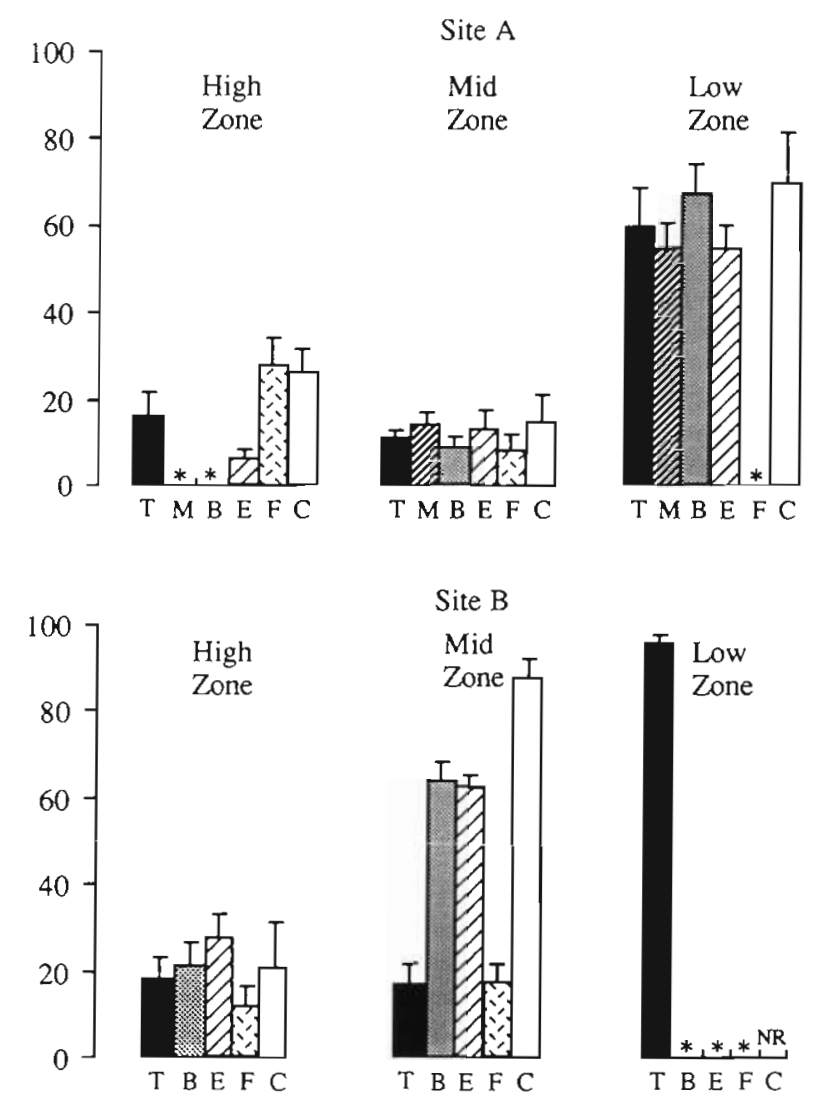

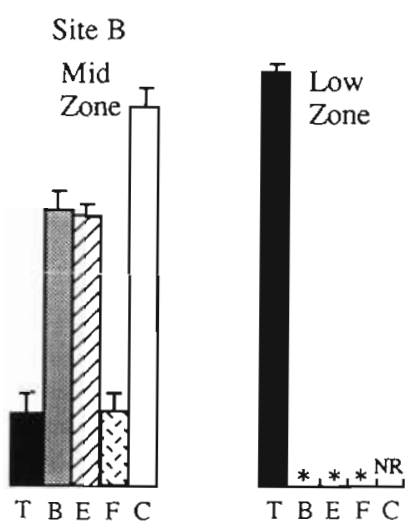

Fig. 4. Semibalanus balanoides. Mean (+ SE) percentage of (a) early post-settlement mortality and (b) post-recruitment mortality for each treatment in the high, mid and low intertidal zones at Sites A and B. Symbols for treatment types given in Table 1. *: No such treatment at that intertidal height; NR: no recruits for that treatment

among treatments (Site A: $F=2.8, p<0.10$; Site B: $F=0.9, \mathrm{p}<0.50$ ) (Fig. $4 \mathrm{~b}$ ). In the mid and low intertidal zones at Site $A$, post-recruitment mortality was not significantly different among treatments (mid: $F=0.7$, $\mathrm{p}<0.65$; low: $F=0.8, \mathrm{p}<0.60$ ), but the low zone had much greater overall post-recruitment mortality (Fig. 4b). In the mid zone at Site B, post-recruitment mortality, in contrast to early post-settlement mortality, was significantly greater in treatments with a canopy of Fucus spp. than in treatments in which Fucus spp. had been removed $(F=39.6, p \ll 0.001)$ (Fig, $4 \mathrm{~b}$ ). Highest post-recruitment mortality for any treatment $(96 \%)$ occurred in the treatment in which the total community had been denuded in the low intertidal zone at Site B (Fig. 4b).

In general, treatments in the high intertidal zone at Site A which had high early post-settlement mortality also had low post-recruitment mortality and viceversa. Therefore, the relative density of barnacles among treatments on 27 September (about 3.5 mo after the main period of settlement) was similar to that at the time of settlement (Table 2). In this zone, the treatment in which the total community had been removed had significantly less barnacles than in the treatment in which Fucus spp. had been removed or in the control treatment $(F=7.4, \mathrm{p}<0.01)$ (Table 2$)$. In the high zone at Site $B$, the density of barnacles on 27 September was not significantly different among treatments $(F=1.3$, $p<0.35$ ) (Table 2), although, as at Site $A$, it was lowest in the treatment in which the total community had been removed. In the mid intertidal zone at Site $A$, there were no significant differences in early postsettlement mortality or post-recruitment mortality among treatments and the density of barnacles on 27 September, like the density of settlers, was not significantly different among treatments $(F=1.4, p<0.30)$ (Table 2). In the mid zone at Site $B$, treatments with high early post-settlement mortality (i.e. treatments without Fucus spp.) also had low post-recruitment mortality and vice-versa. Therefore, the density of barnacles on 27 September, like the density of settlers, was not significantly different among treatments $(F=$ $2.5, \mathrm{p}<0.10$ ) (Table 2). In the low intertidal zone at Site $A$, the density of barnacles on 27 September was sig- 
nificantly lower in the control treatment than in treatments in which only ephemeral algae had been removed or the total community had been removed ( $F=$ 3.6. $\mathrm{p}<0.05$ ) (Table 2). In the low intertidal zone at Site $B$, the density of barnacles on 27 September was extremely low $\left(<2\right.$ ind. $\left.100 \mathrm{~cm}^{-2}\right)$ because of the high post-recruitment mortality in this zone.

\section{DISCUSSION}

The density of settling barnacles Semibalanus balanoides at Sandy Cove was directly related to the availability of free space on the substratum in the mid and low intertidal zones at Site A. However, comparison of settlement patterns among treatments in these zones from the onset of settlement until the end of the main period of settlement indicates selection by cyprids arriving early in the settlement period, when availability of free space was highest, for locations in which only barnacles had been removed. Larvae that arrived later appeared to be restricted to less favourable locations where free space was still available, as free space on favourable sites became limiting Alternatively, cyprids may be less discriminating as they become older (Doyle 1975, Rittschof et al. 1984), assuming that larvae arriving later in the settlement period are older.

In the mid intertidal zone at Site $A$, the density of settlers that accumulated from the onset of settlement until the end of the main period of settlement was not significantly different among treatments, however, there were significant differences among treatments at different times during this period of settlement. Therefore, the detection of settlement preferences of larvae may be confounded when the duration of an experiment is too long. This evidence supports Gaines \& Roughgarden's (1985) contention that the individual settling behaviour of cyprids may be masked when the supply of larvae is great (also see Pyefinch 1948).

The initial selection by cyprids of quadrats in the mid and low intertidal zones in which only barnacles had been removed may have been mediated by settlement cues left by detached adults. Settlement of barnacles in response to conspecific cues is well documented in laboratory (Knight-Jones 1953, Knight-Jones \& Crisp 1953) and field (Raimondi 1988b) experiments. Quadrats which had been denuded and the substratum burned, removing all traces of previous barnacle occupancy, initially received relatively few settlers.

The low number of barnacles settling in the natural community in the low intertidal zone at Site $A$ may be the result of a threshold level of available free space below which planktonic cyprids will not readily settle. Chabot \& Bourget (1988) showed that settlement of
Semibalanus balanoides increased with increasing adult cover up to $30 \%$ in the Bay of Fundy and $22 \%$ in the Gulf of St Lawrence above which settlement declined, probably due to avoidance of densely colonised areas (also see Meadows 1969). In our study, there was, on average, only $30 \%$ free space available for settlement in the natural community, and cyprids may have avoided these crowded areas. Alternatively, these larvae may have been filtered by mussels which were abundant in this zone (Barnes 1959, Mileikovsky 1974. Woodin 1976).

In the high intertidal zone, differential settlement among treatments may represent active selection by cyprids of substrata according to wetness. In the high zone at Site $A$, treatments with ephemeral algae had significantly more settlers, and were wetter during low tide, than those in which ephemeral algae had been removed. Strathmann \& Branscomb (1979) found that cyprids of the barnacle Balanus cariosus settling in the high intertidal region selected surfaces which were moist at low tide rather than nearby drier surfaces, and hypothesized that cyprids were able to detect these differences between surfaces when the substratum is immersed. Settling in areas that retain water or remain damp during low tide increases a cyprid's chance of survival during exposure during low tide because of the reduced risk of desiccation or heat stress (Dayton 1971. Strathmann \& Branscomb 1979, Wethey 1983, Dungan 1985). Dried out cyprids were observed in quadrats with no algal cover in the high zone.

Canopy-forming fucoids may enhance settlement by shading the substratum (Crisp \& Ritz 1973) or interfere with settlement due to fucoid whiplash (see Menge 1976, Grant 1977, Hawkins 1983, Petraitis 1983). In the high zone at Site A, however, the density of settlers in the treatment in which Fucus spp. had been removed was similar to that in the control treatment suggesting that there was no net effect of fucoids on settlement. This may be because, in the high zone, the canopy was sparse $(<35 \%$ cover) and the fronds of Fucus spp. were relatively short in this 1 -yr-old developing community.

Strathmann et al. (1981) showed that some component of the intertidal flora cues settlement of Balanus cariosus and that cyprids preferred areas where algae were more abundant. Ephemeral algae also may guide the settlement of Semibalanus balanoides, since the density of settlers in the high zone at Site A was significantly greater in treatments with ephemeral algae than in treatments where ephemerals had been removed. Microflora also may influence barnacle settlement since a film on the rock surface was most developed in the control treatment and in the treatment in which Fucus spp. had been removed, less developed in the treatment in which ephemeral algae 
had been removed, and least developed in the treatment in which the total community had been removed. Le Tourneux \& Bourget (1988) proposed that the diatom Achnantes parvula might be a positive settlement cue and the ephemeral alga Urospora wormskjoldii could inhibit settlement by larvae of $S$. balanoides. Urospora sp. and diatoms present at Sandy Cove also may direct settlement in the high intertidal zone where desiccation is potentially great.

At Site A, early post-settlement mortality increased from the low to the high intertidal zone in treatments in which algae had been removed and remained very similar or declined in the control treatment or in the treatment in which only barnacles had been removed. This may reflect increased desiccation stress higher on shore and in the absence of algae which retain moisture. In the high intertidal zone at Site A, it appears that factors which influence initial selection of the substratum by cyprid larvae (e.g. the presence of ephemeral algae) also promote early post-settlement survival, and thus, are of primary importance in determining the subsequent population structure of barnacles.

In the low intertidal zone at Site $\mathrm{A}$, early postsettlement mortality was significantly less in the treatment in which the total community had been removed than in the control treatment. Since desiccation is minimal in the low intertidal zone, and densities of settlers were not large enough to result in densitydependent mortality (see Minchinton \& Scheibling 1991), settling in quadrats which had been denuded is advantageous because there are no other macrobenthic species present that could dislodge recently settled spat or obstruct feeding and growth. Post-recruitment mortality in all treatments in the low intertidal zone at Site $A$ was high due to predation by the whelk Nucella lapillus, and to a lesser extent, overgrowth by mussels. Differences in post-recruitment mortality among treatments in the mid intertidal zone at Site B reflect differences in predation pressure by whelks that are related to the presence of a canopy of Fucus spp. Whelks shelter under the canopy of Fucus spp. at low tide which provides a refuge from desiccation (Menge 1978). In the treatment in which the canopy of Fucus spp. had been removed there were fewer whelks, and those present were usually found at the perimeter of the quadrat near Fucus spp. in the surrounding natural community. Unlike the mid intertidal zone, desiccation is reduced in the low intertidal zone and whelks are not restricted to treatments with an algal canopy. Whelks were much less abundant in the mid zone at Site $A$, and postrecruitment mortality was small and not significantly different among treatments. Where predation is intense, initial selection of the substratum by cyprid larvae may have little effect on the subsequent population structure of barnacles.
Differences in settlement and recruitment in the mid and low intertidal zones between sites (see Table 2) may be due to differences in larval supply and local hydrodynamics which prevent settlement of larvae. Site $A$ is more protected from wave action than Site $B$, resulting in reduced water flow in the mid and low intertidal zones which may enhance cyprid settlement (Walton-Smith 1946, Crisp 1955, Wethey 1986, Mullineaux \& Butman 1991). Additionally, reduced water velocity may allow a larva to be more discriminating when choosing a suitable substratum for settlement. If water velocity is high, settlement of larvae may be a function of the availability of free space, but as water velocity is reduced larvae may be able to actively discriminate among settlement sites. Differences in selection of the substratum by larvae may also be more evident in areas of high physiological stress (e.g. high intertidal zone), where the consequences of not settling in a suitable location are more severe, than in areas of low physiological stress (e.g. low intertidal zone).

The influence of active selection of the substratum by cyprids on the final structure of the population may be particularly important as a community develops after a large-scale disturbance event, such as ice scour. In a developing community, biogenic microhabitats are created which may be beneficial to the settlement and recruitment of particular organisms. Once established, these species may influence the settlement dynamics of subsequent cohorts of their own and other species. Understanding habitat preferences of barnacle cyprids (and other marine invertebrates) in this relatively heterogeneous environment may help to explain the population structure of adults.

Acknowledgements. We thank Terry Parker for willingly enduring another frosty winter at Sandy Cove. Eric Mills, Tony Chapman, Jon Grant and Pete Wangersky provided valuable comments on an earlier draft of the manuscript. We are grateful to the people of the National Research Council Aquaculture Station at Sandy Cove for allowing us to perform our field work on their property. Three anonymous reviewers furnished numerous suggestions that enhanced the clarity of the manuscript. T.E.M. was supported by a Natural Sciences and Engineering Research Council (NSERC) Postgraduate Scholarship and a Dalhousie University Graduate Scholarship. The research was funded by an NSERC Operating Grant to R.E.S.

\section{LITERATURE CITED}

Barnes, H. (1955). The growth rate of Balanus balanoides (L.). Oikos 6: 109-113

Barnes, H. (1959). Stomach contents and microfeeding of some common cirripedes. Can. J. Zool. 37: 231-236

Bousfield, E. L. (1953). The distribution and spawning seasons of barnacles on the Atlantic coast of Canada. Bull. natn. Mus. Can. 132: 112-154 
Bushek, D. (1988). Settlement as a major determinant of intertidal oyster and barnacle distributions along a horizontal gradient. J. exp. mar. Biol. Ecol. 122: 1-18

Caffey, H. M. (1985). Spatial and temporal variation in the settlement and recruitment of intertidal barnacles. Ecol. Monogr. 55: 313-335

Chabot, R., Bourget, E. (1988). Influence of substratum heterogeneity and settled barnacle density on the settlement of cypris larvae. Mar. Biol. 97: 45-56

Connell, J. H. (1985). The consequences of variation in initial settlement vs. post-settlement mortality in rocky intertidal communities. J. exp. mar. Biol. Ecol. 93: 11-45

Crisp, D. J (1955). The behavior of barnacle cyprids in relation to water movement over a surface. J. exp. Biol. 32: $569-590$

Crisp, D. J. (1961). Territorial behavior in barnacle settlement J. exp. Biol. 38: 429-446

Crisp, D. J. (1974). Factors influencing the settlement of marine invertebrate larvae. In: Grant, P. T., Mackie, A. M (eds.) Chemoreception in marine organisms. Academic Press, New York, p. 177-205

Crisp, D. J., Barnes, H. (1954). The orientation and distribution of barnacles at settlement with particular reference to surface contour. J. Anim. Ecol. 23: 142-162

Crisp, D. J., Meadows, P. S. (1962). The chemical basis of gregariousness in cirripedes. Proc. R. Soc. (Ser. B.) 156 $500-520$

Crisp, D. J., Meadows, P. S. (1963). Adsorbed layers: the stimulus to settlement in barnacles. Proc. R. Soc. (Ser. B.) 158: $364-387$

Crisp, D. J., Ritz, D. A. (1973). Responses of cirripede larvae to light. 1. Experiments with white light. Mar. Biol. 23 $327-335$

Davis, A. R. (1988). Effects of variation in initial settlement on distribution and abundance of Podoclavella moluccensis Sluiter. J. exp. mar. Biol. Ecol. 117: 157-167

Dayton, P. K. (1971). Competition, disturbance and community organization: the provision and subsequent utilization of space in a rocky intertidal community. Ecol. Monogr. 41: $351-389$

Denley, E. J., Underwood, A. J. (1979). Experiments on factors influencing settlement, survival, and growth of two species of barnacles in New South Wales. J. exp. mar. Biol. Ecol. 36: 269-293

Doyle, R. W. (1975). Settlement of planktonic larvae: a theory of habitat selection in varying environments. Am. Nat. 109: $113-126$

Dungan, M. L. (1985). Competition, and the morphology, ecology, and evolution of acorn barnacles: an experimental test. Paleobiology 11: 165-173

Gaines, S., Roughgarden, J. (1985). Larval settlement rate: a leading determinant of structure in an ecological community of the marine intertidal zone. Proc. natn. Acad. Sci. U.S.A. 82: $3707-3711$

Grant, W. S. (1977). High intertidal community organization on a rocky headland in Maine, USA. Mar. Biol. 44: 15-25

Grosberg, R. K. (1982). Intertidal zonation of barnacles: the influence of planktonic zonation of larvae on vertical distribution of adults. Ecology 63: 894-899

Hawkins, S. J. (1983). Interactions of Patella and macroalgae with the settling of Semibalanus balanoides. J. exp. mar. Biol. Ecol. 71: 55-72

Hudon, C., Bourget, E. (1981). Initial colonization of artificial substrate: community development and structure studied by scanning electron microscopy. Can. J. Fish. Aquat. Sci. 38: 1371-1384

Hudon, C., Bourget, E., Legendre, P. (1983). An integrated study of factors influencing the choice of a settling site of Balanus crenatus cyprid larvae. Can. J Fish. Aquat. Sci. 40: $1186-1194$

Keough, M. J., Downes, B. J. (1982). Recruitment of marine invertebrates: the role of active larval choice and early mortality. Oecologia 54: 348-352

Knight-Jones, E. W. (1953). Laboratory experiments on gregariousness during settling in Balanus balanoides and other barnacles. J. exp. Biol. 30:584-598

Knight-Jones, E. W., Crisp, D. J. (1953). Gregariousness in barnacles in relation to the fouling of ships and to antifouling research. Nature 171: 1109-1110

Larman, V. N., Gabbott, P. A. (1975). Settlement of cyprid larvae of Balanus balanoides and Elminius modestus induced by extracts of adult barnacles and other marine animals. J. mar. biol. Ass. U.K. 55: 183-190

Le Tourneux, F., Bourget, E. (1988). Importance of physical and biological settlement cues at different spatial scales by the larvae of Semibalanus balanoides. Mar. Biol. 97; $57-66$

Lewis, C. A. (1978). A review of substratum selection in freeliving and symbiotic cirripeds. In: Chia, F. S., Rice, M. E. (eds.) Settlement and metamorphosis of marine invertebrate larvae. Elsevier/North Holland, New York, p $207-218$

Luckens, P. A. (1970). Breeding, settlement and survival of barnacles at artificially modified shore levels at Leigh, New Zealand. N.Z. J. mar. Freshwat. Res. 4: 497-514

Maki, J. S., Rittschof, D., Costlow, J. D., Mitchell, R. (1988). Inhibition of attachment of larval barnacles, Balanus amphitrite, by bactenal surface films. Mar. Biol. 97: 199-206

Meadows, P. S. (1969). Settlement, growth and competition in sublittoral populations of barnacles. Hydrobiologia 33: $65-92$

Menge, B. A. (1976). Organization of the New England rocky intertidal community: role of predation, competition and environmental heterogeneity. Ecol. Monogr. 46: 355-393

Menge, B. A. (1978). Predation intensity in a rocky intertidal community. Effect of an algal canopy, wave action and desiccation on predator feeding rates. Oecologia 34 : $17-35$

Mileikovsky, S. A. (1974). On predation of pelagic larvae and early juveniles of marine bottom invertebrates by adult benthic invertebrates and their passing alive through their predators. Mar. Biol. 26: 303-311

Minchinton, T E., Scheibling, R. E. (1991). The influence of larval supply and settlement on the population structure of barnacles. Ecology 72: 1867-1879

Mullineaux, L. S., Butman, C. A. (1991). Initial contact, exploration and attachment of barnacle (Balanus amphitrite) cyprids settling in flow. Mar. Biol. 110: 93-103

Petraitis, P. S. (1983). Grazing patterns of the periwinkle and their effect on sessile intertidal organisms. Ecology 64: $522-533$

Pyefinch, K. A. (1948). Notes on the biology of cirripedes. J. mar. biol. Ass. U.K. 27: 464-503

Raimondi, P. T. (1988a). Rock type affects settlement, recruitment, and zonation of the barnacle Chthamalus anisopoma Pilsbury. J. exp. mar. Biol. Ecol. 123: 253-267

Raimondi, P. T (1988b). Settlement cues and determination of the vertical limit of an intertidal barnacle. Ecology 69: 400-407

Rittschoff, D., Branscomb, E. S., Costlow, J. D. (1984). Settlement and behavior in relation to flow and surface in larval barnacles, Balanus amphitrite Darwin. J. exp. mar. Biol. Ecol. 82: 131-146

Roughgarden, J., Iwasa, Y., Baxter, C. (1985). Demographic 
theory for an open marine population with space-limited recruitment. Ecology 66: 54-67

Roughgarden, J., Gaines, S. D., Pacala, S. W. (1987). Supplyside ecology: the role of physical transport processes. In: Giller, P., Gee, J. (eds.) Organization of communities: past and present. Proc. British Ecological Society Symp., Aberystwyth, Wales (April 1986). Blackwell Scientific, London, p. 491-518

Strathmann, R. R., Branscomb, E. S. (1979). Adequacy of cues to favorable sites used by settling larvae of two intertidal barnacles. In: Stancyk, S. E. (ed.) Reproductive ecology of marine invertebrates. Univ. of South Carolina Press Columbia, p. 77-89

Strathmann, R. R., Branscomb, E. S., Vedder, K. (1981). Fatal errors in set as a cost of dispersal and the influence of intertidal flora on settlement of barnacles. Oecologia 48 : $13-18$

Underwood, A. J., Denley, E. J. (1984). Paradigms, explanations and generalizations in models for the structure of intertidal communities on rocky shores. In: Strong. D. R., Simberloff, D., Abele, L. G., Thistle, A. B. (eds.) Ecological communities: conceptual issues and the evidence. Princeton Univ. Press, Princeton, p. 151-180

Underwood, A. J., Fairweather, P. G. (1989). Supply-side

This article was submitted to the editor ecology and benthic marine assemblages. Trends Ecol. Evol. (TREE) 4: 16-20

Walton-Smith, F. G. (1946). Effect of water currents upon attachment and growth of barnacles. Biol. Bull. 90: 51-70

Wethey, D. S. (1983). Geographic limits and local zonation: the barnacles Semibalanus (Balanus) and Chthamalus in New England. Biol. Bull. 165: 330-341

Wethey, D. S. (1984). Spatial patterns in barnacle settlement: day to day changes during the settlement season. J. mar. biol. Ass. U.K. 64: 687-698

Wethey, D. S. (1986). Ranking of settlement cues by barnacle larvae: influence of surface contour. Bull. mar. Sci. 39: $393-400$

Woodin, S. A. (1976). Adult-larval interaction in dense infaunal assemblages: patterns of abundance. J. mar. Res. 34: $25-41$

Young, C. M. (1987). Novelty of 'supply-side' ecology. Science 235: $415-416$

Yoshioka, P. M. (1982). Role of planktonic and benthic factors in the population dynamics of the bryozoan Membranipora membranacea. Ecology 63: 457-468

Zar, J. H. (1984). Biostatistical analysis, 2nd edn. PrenticeHall, Inc., Englewood Cliffs

Manuscript first received: April 11, 1990

Revised version accepted: January 21, 1993 